\title{
Customer service on the Web: A cross-industry investigation
}

Received (in revised form): 27th November, 2001

\section{Ron Lennon}

is Professor of Marketing at Barry University, Miami, Florida, and has published articles on various topics in Journal of Vacation Marketing; Mountain Plains Journal of Business and Economics; Journal of the Association of Marketing Educators; Journal of Homosexuality; Progress in Tourism and Hospitality Research; International Journal of Contemporary Hospitality Management and Cornell HRA Quarterly; and forthcoming articles in Tourism Analysis; Journal of Hospitality and Leisure Management and Economics and Management. In addition, he has presented numerous papers at professional conferences.

\section{Judy Harris}

is an Assistant Professor of Marketing at the University of Central Florida in Orlando, Florida. Her PhD is from the University of Houston in Houston, Texas. Her work has appeared or will soon appear in the Journal of Consumer Research, Journal of Retailing, Journal of Applied Social Psychology, Psychology and Marketing and others.

Ron Lennon

Andreas School of Business, Barry University, Miami, FL 33161, USA.

Tel: +1 305 899-3507; Fax: +1 305892 6412; e-mail: rlennon@mail.barry. edu

\begin{abstract}
In this paper, the authors examine how the extent and quality of customer service varies between online companies in industries that are more or less customer-oriented. Specifically, they explore how the customer service provided by online firms in the more customer-oriented industries of travel and retailing compares to the service provided by online firms in the less customer-oriented industries of manufacturing and technology. In addition, they examine how the amount of firm's Web experience relates to the quality of customer service. Although they find that the quality of customer service available from online firms seems to be consistently poor, there is plenty of room for newer, smaller firms to compete on the service dimension. Specific implications and recommendations are discussed.
\end{abstract}

\section{INTRODUCTION}

Good customer service is hard to find. Studies by groups ranging from the Council of Better Business Bureaus, Inc. ${ }^{1}$ the University of Michigan ${ }^{2}$ and the International Customer Service Association $^{3}$ indicate what consumers themselves already know — good customer service is increasingly rare. Anecdotal evidence backs up these findings with vivid examples of customer discontent. Witness the growing number of 'anti-company' websites dedicated to cataloguing poor service ${ }^{4}$ — over 300 listed on Yahoo! alone. ${ }^{5}$

Customers attempting to obtain customer service from an online firm may encounter even poorer service than customers interacting with a firm face-to-face. Many Internet businesses are start-ups that have limited resources to allocate to customer retention and limited first-hand knowledge of the importance of goodwill. In fact, online businesses have been known not to list a phone number to call about problems, or hide it so deep in the website that customers are unable to find it. For example, a representative of CheapTickets.com actually admitted to one of the author's that they buried the company's phone number and address deep in the website, for fear that customers would actually call with complaints (they have since changed this policy). 
Hiding from potentially unsatisfied customers does not seem like a particularly sure path to success, and it is unlikely that a business operating only in a traditional format would survive long with such a policy. In the virtual new world of the Internet, however, this is not a foregone conclusion. 'Service with a smile' counts for little online, and customers searching for information and/or making purchases online may have very different service expectations than traditional bricks-and-mortar customers. ${ }^{6}$ If, for example, the majority of businesses in a particular industry provide less than exceptional online service, the consumer may simply learn to adapt to such treatment.

This paper explores this issue. Specifically, it examines how the extent and quality of online customer service varies between businesses in industries that are more or less customer-oriented and between businesses of varying sizes and experience levels. This comparison results in a clearer picture of the state of online customer service than is currently available in the literature. In addition, it allows for theoretical generalisations about the availability of customer service among different types of firms and has implications for the degree to which businesses in various industries can use customer service as a competitive differentiator.

The paper is organised as follows. First, the way industry and firm characteristics are likely to influence the quality and extent of customer service are discussed and six hypotheses that stem from these issues are presented. Although online customer service is an increasingly popular topic in the business press, little academic work has focused on the topic. Secondly, the results of a content analysis of the extent and quality of customer service available on over 100 websites of companies spanning four industries and a variety of sizes and experience levels are presented. Finally, the implications of the results are discussed.

\section{IMPORTANCE OF ONLINE CUSTOMER SERVICE}

Good customer service has become increasingly important for online companies. Customer service has been called the key factor in determining which companies will survive and which will not, ${ }^{7}$ and is vital to ensuring the repeat visits that lead to escalating future sales and increased lifetime value of the customer. ${ }^{8}$ Good customer service online might also affect a business' offline operations. For example, a study by Jupiter found that 70 per cent of online buyers would spend less money at the 'bricks and mortar' store if they suffered poor customer service at the merchant's website. ${ }^{9}$

Online customers are becoming not only more plentiful, but also more demanding. This presents both a challenge and an opportunity. With the competition only a click away, the pressure is on every e-business to distinguish itself with better customer service. For example, e-businesses cannot take days to respond to e-mail inquiries and expect customers to keep coming back. ${ }^{10}$ Says Jeanette Brown of Business Week, 'good customer service is the best investment an e-business can make'. ${ }^{11}$

Despite the hype about the Web ushering in a new era of customer care, examples of bad service on the Internet abound. A 2000 survey conducted by the National Association of Consumer Agency Administrators and the Consumer Federation of America found that complaints about the Internet were the fastest growing of any type of consumer complaint. ${ }^{12}$ They found that 39 per cent of its agencies had received 
complaints about merchandise ordered over the Internet - compared to 27 per cent which had received complaints about merchandise from mail order catalogues. Common complaints range from not following up customers' questions or complaints, to not even providing information on how to obtain customer service. On a similar note, a recent examination of 50 retail sites by the Gartner Group ${ }^{13}$ rated none as excellent or good and less than a quarter as average. Only 10 per cent of sites surveyed allowed customers to track inquiries through to resolution, 6 per cent offered a feature asking the retailer to call the customer, 24 per cent had instant messaging and only 28 per cent acknowledged that an e-mail inquiry was received.

\section{CUSTOMER ORIENTATION}

Which companies are likely to provide the best customer service? By definition, companies that are more

customer-oriented should do the best job. Such companies have a better understanding of their target buyers ${ }^{14}$ and put customer interests first. ${ }^{15}$ Companies with a strong customer orientation have a commitment to their customers and to creating customer value; they are likely to understand customer needs, measure customer satisfaction and provide better after sales service. ${ }^{16}$

Past research in the customer orientation area has not specifically compared industries in terms of their degree of customer orientation, instead concentrating on only one industry ${ }^{17}$ or including multiple industries only to ensure generalisability. ${ }^{18}$ It is likely, however, that companies in some industries will be more customer-oriented than companies in others. Manufacturing companies may have a harder time assessing customer needs than companies farther along the distribution channel because they must deal not only with the end user but also with intermediaries. ${ }^{19}$ Companies in the 'technology turbulent' high-tech industry are likely to consider a customer orientation to be less important than a product orientation because these companies must be focused on $\mathrm{R} \& \mathrm{D}$, rather than customer research, to be truly innovative. $^{20}$

On the other hand, companies in the travel and retailing industries should, in general, be more customer-oriented. Unlike manufacturers, companies in these industries can focus on the end users more. Additionally, the high service component in these industries, the breadth of merchandise offered and the similarity of merchandise among competitors make a customer orientation necessary to achieve success. ${ }^{21}$

\section{HYPOTHESES}

\section{Customer orientation}

Based on the preceding discussion, the authors developed three hypotheses related to the extent of customer service activities offered by firms in industries that are more or less customer oriented. Specifically, they hypothesise:

$\mathrm{H}_{1}$ : Websites of firms in more customer-oriented industries will be more likely to provide multiple customer communication channels than will websites of firms in less customer-oriented industries.

$\mathrm{H}_{2}$ : Websites of firms in more customer-oriented industries will require more personal information from customers who submit service-related questions than will companies in less customer-oriented industries. 
$\mathrm{H}_{3}$ : Websites of firms that accept credit card information online will be more likely to provide a security statement than will websites that do not accept credit card information, particularly in more customer-oriented industries.

The rationale underlying these hypotheses is as follows. Companies in the more customer-oriented industries of travel and retailing should place more emphasis on customer communication, personal relationships and customer satisfaction than do companies in the less customer-oriented industries of manufacturing and technology. In addition, the preponderance of particular types of communication channels available should differ depending on the industry. Specifically, the authors expected that companies in the more customer-oriented industries of retail and travel industry would be more likely to provide multiple channels of communication, including toll-free telephone numbers and postal addresses, than companies in the less consumer-oriented industries of technology and manufacturing.

Companies in the technology industry, on the other hand, should be more likely to provide e-mail addresses than they are to provide toll-free telephone numbers and postal addresses.

Moreover, companies that deal directly with the customer rather than through intermediaries were expected to be more likely to place a greater emphasis on building a relationship with site visitors and to engage in direct marketing efforts. Consequently, these more customer-oriented firms should be more likely to require personal information from customers when submitting service-related questions than will companies in the less customer-oriented industries of manufacturing and technology. These firms should also be more sensitive to their customers' security concerns.

\section{Quality of customer service}

In addition, the authors examined how variables related to size and Internet experience would affect the quality of customer service. Specifically, they hypothesised that firms that are larger (have more Web experience) will generally offer superior customer service than will firms that are smaller (have less Web experience). They believed this to be likely both because firms with more resources and/or years of experience may be better able to allocate resources to customer care and because, over time, the 'survival of the fittest' may have resulted in those firms offering better service becoming larger and/or more experienced. Stated formally:

$\mathrm{H}_{4}$ : The quality of customer service provided on the website will be higher for firms in more customer -oriented industries than for firms in less customer-oriented websites.

$\mathrm{H}_{5}$ : The quality of customer service provided on the website will be higher for larger firms than for smaller firms.

$\mathrm{H}_{6}$ : The quality of customer service provided on the website will be higher for firms with more experience on the Internet than for firms with less experience on the Internet.

\section{METHOD}

\section{Sample of sites}

A total of 103 company sites were chosen to represent the more 
customer-oriented industries of travel and retailing and the less customer-oriented industries of technology and manufacturing. The sample included 26 travel-related sites, 28 sites affiliated with retail stores, 22 sites operated by firms that manufacture consumer products, and 26 sites operated by hardware, software and other technology-related firms. The research was conducted in the USA, using both domestic as well as international websites during April, 2001.

\section{Measures}

Channels of communication. For each site, the communications options available to visitors seeking customer service was assessed. The presence or absence of a toll-free telephone number, an e-mail address and a postal address were noted for each site.

Personal information. For each site, whether or not personal information, such as name and e-mail address was requested from a visitor when attempting to e-mail the firm with a customer service question was determined. Firms that did not provide an e-mail address were coded as not collecting personal information. In addition, track was kept of those firms which automatically added a visitor to an e-mail list after a question was asked.

Security. For each site, whether or not a security statement explaining privacy issues was included on the site was determined.

Level of customer service. For each site, the level of customer service provided was assessed, drawing upon those aspects identified by Kleindl. ${ }^{22}$ Kleindl describes seven basic best practices of online customer service

- furnishing product, security and shipping information

- providing link(s) to inventory to determine if products are available
- sending automatic order confirmations

- avoiding fees that are not charged by bricks-and-mortar retailers

- responding to customers quickly

- providing alternative means of contact (toll-free numbers, e-mail, etc.)

- using 'live' individuals to support automated functions.

For this study, six aspects of service were evaluated:

- response time: the number of minutes it took for a customer service employee to answer the telephone when called with a customer service question

- time to find information: the number of minutes it took for the customer service employee to find the name and address of the president of the firm. This would be important information for a customer planning to write to the company about a service issue

- number of ways to contact the firm: three communication channels were measured - toll-free telephone number, e-mail address and a postal address. For each company, the number of channels was summed to calculate a number between zero and three

- human contact: whether or not it was possible to speak to a human customer service representative to answer questions

- pleasantness of employee: the pleasantness of the employee answering the phone was rated on a scale of one to ten by a rater unaware of the purposes and hypotheses of the study. If no answer was received, pleasantness was coded as 0 . As a subjective measure, this rating is subject to some error. The measure was, however, uniform across all company websites 
- link to location where product or service can be purchased: whether or not the page linked the visitor to a location of the product, either on site or at a physical location.

Size of the firm. For each site, the researchers attempted to collect information about the annual revenue and number of employees of the firm as measures of firm size. They were able to obtain this information on about 84 of the companies in the sample from Hoovers Online Business Network. ${ }^{23}$ Firms for which this information was not available were excluded from analyses involving this measure. Annual revenues of the firms ranged from US $\$ 11 \mathrm{~m}$ to US $\$ 105,832 \mathrm{~m}$. The number of employees ranged from 109 to 326,000.

Experience on the Internet. The amount of Internet experience of each firm was measured by the proxy variable of the number of years since the site name was originally registered by the current owner. Although this is not a perfect measure of Internet experience, it is likely that firms that are more 'Internet savvy' are likely to have registered their names with the intention of building a site earlier than other firms. Information about the registration date of each site name was obtained from Network Solutions. ${ }^{24}$ The number of years of Internet experience ranged from zero (name registered in the year 2000) to 14 .

\section{RESULTS}

\section{Hypothesis 1}

Hypothesis 1 concerned the question of whether companies in different industries are likely to encourage customers to communicate through different channels for service-related issues. It was expected that companies in the technology industry are more likely to provide e-mail addresses than they are to provide toll free telephone numbers and postal addresses, and that companies in the more customer-oriented industries of retail and travel industry are more likely to provide toll-free telephone numbers and postal addresses than companies in the less consumer-oriented industries of technology and manufacturing.

To test this expectation, the authors performed a multivariate analysis of variance using the presence/absence of the channels of communication (toll-free number, e-mail address, postal address) as dependent variables and the customer-orientation of the industry (more, less) as the independent variable. This analysis revealed significant effects for orientation on the presence/absence of both a toll-free number $(\mathrm{F}=6.42$, $\mathrm{p}<0.05)$ and an e-mail address $(\mathrm{F}=5.18$, $\mathrm{p}<0.05)$, but not for a postal address $(\mathrm{F}<2.01$, n.s. $)$. As expected, firms in the more consumer-oriented industries of travel and retailing were more likely to provide toll-free numbers than manufacturing companies and technology industries (see Table 1). Companies in the retail and travel industries were less likely to provide an e-mail address compared to manufacturing and technology industries.

The authors also examined the extent to which technology companies would be more likely to encourage communication by e-mail and less likely to encourage communication by more traditional methods. As expected, 64 per cent of technology companies provided e-mail addresses, compared to only 39.5 per cent of non-technology companies $(\mathrm{F}=4.68, \mathrm{p}<0.05)$. In contrast, only 56 per cent of companies within the technology industry included a toll-free number on their website, compared to 81.6 per cent of other industries $(\mathrm{F}=6.93, \mathrm{p}<0.01)$. There was no difference between technology-oriented and non-technology-oriented companies 
Table 1: Availability of communication channels

\begin{tabular}{llll}
\hline Industry & $\begin{array}{l}\text { Proportion with } \\
\text { postal address } \\
\%\end{array}$ & $\begin{array}{l}\text { Proportion with } \\
\text { toll-free number } \\
\%\end{array}$ & $\begin{array}{l}\text { Proportion with } \\
\text { e-mail address } \\
\%\end{array}$ \\
\hline Travel $(\mathrm{n}=26)$ & 61.5 & 80.8 & 34.6 \\
Retail $(\mathrm{n}=28)$ & 64.3 & 89.3 & 35.7 \\
Total: Sites in consumer-oriented industries & 63.0 & 85.2 & 35.2 \\
Manufacturing $(\mathrm{n}=22)$ & 45.5 & 72.7 & 50.0 \\
Technology $(\mathrm{n}=25)$ & 52.0 & 56.0 & 64.0 \\
Total: Sites in less consumer-oriented industries & 48.9 & 63.8 & 57.4 \\
Total: All sites & 56.4 & 75.2 & 45.5 \\
\hline
\end{tabular}

Table 2: Requesting of personal information

\begin{tabular}{lll}
\hline Industry & $\begin{array}{l}\text { Yes } \\
\mathbf{( n = 3 4 )} \\
\%\end{array}$ & $\begin{array}{l}\text { No } \\
\mathbf{( n = 6 7 )} \\
\mathbf{\%}\end{array}$ \\
\hline Travel $(\mathrm{n}=26)$ & 15.4 & 84.6 \\
Retail $(\mathrm{n}=28)$ & 42.9 & 57.1 \\
Total: Sites in consumer-oriented industries & 29.6 & 70.4 \\
Manufacturing $(\mathrm{n}=22)$ & 50.0 & 50.0 \\
Technology $(\mathrm{n}=25)$ & 28.0 & 72.0 \\
Total: Sites in less consumer-oriented industries & 38.3 & 61.7 \\
Total: All sites & 33.7 & 66.3 \\
\hline
\end{tabular}

in regard to the likelihood of providing a postal address $(57.9$ per cent $v$ s. 52.0 per cent, $\mathrm{F}=0.27$, n.s.).

\section{Hypothesis 2}

Hypothesis 2 predicted that firms in the more customer-oriented industries of travel and retailing would require more personal information from customers when submitting service-related questions than would companies in the less customer-oriented industries of manufacturing and technology. The results did not support this prediction (see Table 2). A $\chi^{2}$ test revealed no significant differences between the proportions of sites in more and less customer-oriented industries in regard to the likelihood of requiring personal information $\left(\chi^{2}=0.85\right.$, n.s.). Although the difference was not significant, it is interesting to note that directionally, sites in the less customer-oriented industries were more likely to collect personal information. Potentially, this is because businesses without direct contact with the consumer are more likely to attempt to establish a one-to-one relationship through online methods.

It was the case that more customer-oriented firms seemed to do a better job of continuing contact with a visitor, as such firms were somewhat more likely to add these visitors to an automatic mailing list (more customer-oriented sites: 22.2 per cent; less customer-oriented sites: 10.6 per cent; $\chi^{2}=2.41, \mathrm{p}<0.10$ ).

\section{Hypothesis 3}

Hypothesis 3 predicted that companies that take credit cards would be more 
Table 3: Security statements and acceptance of credit cards

\begin{tabular}{|c|c|c|}
\hline Industry & $\begin{array}{l}\text { Do not accept } \\
\text { credit cards } \\
\%\end{array}$ & $\begin{array}{l}\text { Accept } \\
\text { credit cards } \\
\%\end{array}$ \\
\hline \multicolumn{3}{|l|}{ Travel } \\
\hline No security statement $(n=12)$ & 0.0 & 53.8 \\
\hline Security statement $(n=14)$ & 7.7 & 38.5 \\
\hline \multicolumn{3}{|l|}{ Retail } \\
\hline No security statement $(n=13)$ & 21.4 & 25.0 \\
\hline Security statement $(n=15)$ & 0.0 & 53.6 \\
\hline \multicolumn{3}{|c|}{ Total: Sites in more consumer-oriented industries } \\
\hline No security statement $(n=12)$ & 11.1 & 38.9 \\
\hline Security statement $(n=14)$ & 3.7 & 46.3 \\
\hline \multicolumn{3}{|l|}{ Manufacturing } \\
\hline No security statement $(n=22)$ & 40.9 & 59.1 \\
\hline Security statement $(n=0)$ & 0.0 & 0.0 \\
\hline \multicolumn{3}{|l|}{ Technology } \\
\hline No security statement $(n=10)$ & 0.0 & 40.0 \\
\hline Security statement $(n=15)$ & 12.0 & 48.0 \\
\hline \multicolumn{3}{|c|}{ Total: Sites in less consumer-oriented industries } \\
\hline No security statement $(n=12)$ & 19.1 & 48.9 \\
\hline Security statement $(n=14)$ & 6.4 & 25.5 \\
\hline \multicolumn{3}{|l|}{ Total: All sites } \\
\hline No security statement $(n=12)$ & 14.9 & 43.6 \\
\hline Security statement $(n=14)$ & 4.9 & 36.6 \\
\hline
\end{tabular}

likely to have a statement discussing the security of financial transactions on the site than companies that do not take credit cards. This effect was expected to be stronger for firms in customer-oriented industries than in less customer-oriented industries.

As Table 3 indicates, a series of chi-squared analyses indicated a marginally significant relationship between the presence/absence of a security statement and whether or not the company collected credit card information from the customer $\left(\chi^{2}=2.82, \mathrm{p}<0.10\right)$. Follow-up analyses indicated that this relationship was significant only in the retailing industry $\left(\chi^{2}=8.81, \mathrm{p}<0.05\right.$, all other $\chi^{2} \mathrm{~s}<2.53$, $\mathrm{p}>0.10)$. Surprisingly, more than half of the travel-related sites, more than half of the manufacturing sites, and 40 per cent of the technology sites collected credit card information without having a security statement available.

\section{Hypothesis 4}

Hypothesis 4 predicted that the quality of customer service provided on the website would be higher for firms in more customer-oriented industries than for firms in less customer-oriented industries. To test this hypothesis, a multivariate analysis of variance using the industry (more or less customer-oriented) as an independent variable was performed. The dependent variables were the four scaled customer service dimensions discussed earlier — response time, time to find information, number of ways to contact the firm and pleasantness of the employee. The effects of customer-orientation on the likelihood of having a link to the location of the product and the likelihood of a human contact were assessed with $\chi^{2}$ tests.

Contrary to expectations, the analysis of variance did not indicate any significant differences in the quality of customer service depending on the 
Table 4: Effects of customer orientation on aspects of customer service

\begin{tabular}{|c|c|c|c|c|c|}
\hline Aspect of customer service & Travel & Retail & Manufacturing & Technology & $\begin{array}{l}\text { F-statistic more } \\
\text { vs. less } \\
\text { customer-oriented }\end{array}$ \\
\hline $\begin{array}{l}\text { Number of minutes to answer } \\
\text { phone }\end{array}$ & 2.15 & 2.63 & 2.69 & 1.83 & $\mathrm{~F}=0.80$, n.s. \\
\hline $\begin{array}{l}\text { Number of minutes to find } \\
\text { information about company }\end{array}$ & 3.23 & 2.42 & 2.45 & 3.50 & $\mathrm{~F}=0.82$, n.s. \\
\hline $\begin{array}{l}\text { Average number of } \\
\text { communication channels }\end{array}$ & 1.77 & 1.89 & 1.68 & 1.72 & $\mathrm{~F}=0.99$, n.s. \\
\hline Pleasantness of employee & 7.87 & 7.72 & 7.0 & 7.40 & $F=0.89$, n.s. \\
\hline Proportion linking to product & $96.2 \%$ & $96.4 \%$ & $59.1 \%$ & $96.0 \%$ & $\chi^{2}=7.41, p<0.01$ \\
\hline $\begin{array}{l}\text { Proportion allowing for human } \\
\text { contact }\end{array}$ & $53.8 \%$ & $53.6 \%$ & $27.3 \%$ & $40.0 \%$ & $\chi^{2}=3.93, p<0.05$ \\
\hline
\end{tabular}

customer orientation of the firm. At least as measured here, sites of businesses in industries that are typically more customer-oriented do not provide greater customer service than do sites in typically less customer-oriented industries.

Significant differences were, however, found in the proportional tests. As expected, sites in the more customer-oriented travel and retail industries were significantly more likely to provide a link to the product $\left(\chi^{2}=7.41, \mathrm{p}<0.01\right)$. This is probably to do with the fact that customer-oriented firms, by virtue of being closer to the consumer, are also more likely to offer online ordering and delivery options. Also as expected, sites in the more customer-oriented industries were more likely to provide a human contact to answer questions $\left(\chi^{2}=3.93, \mathrm{p}<0.05\right)$ than were sites in the less customer-oriented manufacturing and technology industries. These findings provide partial support of Hypothesis 4 (see Table 4).

\section{Hypothesis 5}

Hypothesis 5 predicted that the level of quality of customer service for Web-based companies would vary with the size of the firm. As discussed earlier, size was measured by each firm's annual revenue and number of employees. Due to the extreme variance among the companies in regard to both annual revenue $(\sigma=18,275.65)$ and number of employees $(\sigma=70,023.83)$, these variables were recoded into the categories of small, medium and large. Because of the correlation between these variables $(\rho=0.59, \mathrm{p}<0.01)$, they were combined into a single measure. Small companies were defined as those companies ranked as small in regard to both revenue and number of employees $(n=23)$, large companies were defined as those ranked large on at least one variable $(n=32)$, and medium companies were defined as those ranked in between $(n=29)$. Fewer sites were included in this analysis because of the lack of size data for some firms.

As with Hypothesis 4, a multivariate analysis of variance was conducted to assess the effects of size of the company on the four scaled customer service variables, and a $\chi^{2}$ test was performed on the link to location and human contact variables.

Size influenced neither the number of communication channels available nor the pleasantness of the employees, but did have a significant effect on the response time $(\mathrm{F}=4.75, \mathrm{p}<0.05)$. As expected, larger firms, which are likely to have more resources, tend to answer 
Table 5: Effects of company size on aspects of customer service

\begin{tabular}{lcccl}
\hline Aspect of customer service & Small & Medium & Large & F-statistic \\
\hline Number of minutes to answer phone & 3.39 & 2.43 & 1.67 & $\mathrm{~F}=4.75, \mathrm{p}<0.05$ \\
Number of minutes to find information about company & 5.94 & 6.24 & 5.04 & $\mathrm{~F}=0.59, \mathrm{n} . \mathrm{s}$. \\
Average number of communication channels & 1.61 & 1.41 & 1.50 & $\mathrm{~F}=0.06$, n.s. \\
Pleasantness of employee & 7.82 & 7.13 & 7.06 & $\mathrm{~F}=0.03$, n.s. \\
Proportion linking to product & $87.0 \%$ & $86.2 \%$ & $84.4 \%$ & $\chi^{2}=0.82$, n.s. \\
Proportion allowing for human contact & $47.8 \%$ & $62.1 \%$ & $37.5 \%$ & $\chi^{2}=3.67$, n.s. \\
\hline
\end{tabular}

customer service queries directed from the site more quickly than are smaller firms. Contrary to expectations, size of the firm was not significantly related to the likelihood of linking to product location or human contact (see Table 5). Interestingly, although the difference was not significant, the proportion of sites allowing for human contact was directionally less for larger firms. Larger firms, because of their sheer size, should be more likely to use automated answering systems. Such systems, although they do not preclude the additional use of human customer service personnel, seem from these findings to make it less likely. This result also explains, at least in part, the earlier finding that larger firms are quicker to respond to customer service calls.

\section{Hypothesis 6}

Hypothesis 6 predicted that the level of customer service for Web-based companies will depend upon the number of years of experience possessed by the company. Correlational analyses indicated that the number of years of experience was significantly related to two of the measures of customer service quality. Interestingly, companies with more experience generally offered poorer service quality. The number of years of experience was positively related to the number of minutes it took to answer questions $(\rho=0.42, \mathrm{p}<0.01)$ and negatively related to the number of methods of contact available $(\rho=-0.21$, $\mathrm{p}<0.05)$. Neither the number of minutes it took to answer the phone $(\rho=0.04$, n.s. $)$ nor the pleasantness of the operator $(\rho=-0.18$, n.s $)$ was significantly correlated with the experience of the company.

To test the relationship between the number of years of experience and the likelihood of linking to the product and human contact, separate binary logistic regressions using the years of experience as the independent variable, and each of the two categorical customer service variables as the dependent variables were performed. Sites with more experience were more likely to provide a link to the product, although this relationship only approached significance $\left(\chi^{2}=2.54\right.$, $\mathrm{p}=0.11 ;$ mean years, no link $=3.75$; mean years, link $=4.91)$. Contrary to expectations, sites with more experience were significantly less likely to allow for human contact $\left(\chi^{2}=3.79, \mathrm{p}<0.05\right.$; mean years, no human $=5.20$; mean years, human $=4.24$ ). As seen with company size, it is again seen that businesses seem to be trading off customer service with efficiency as they grow (see Table 6).

\section{DISCUSSION}

This paper has explored the extent and quality of online customer service.

Although online customer service is an increasingly 'hot' topic in the business world as both competitive pressures and 
Table 6: Relationship between customer service with years of Web experience

\begin{tabular}{|c|c|c|}
\hline Aspect of customer service & $\begin{array}{l}\text { Correlation with years } \\
\text { of experience }\end{array}$ & Significance level \\
\hline Number of minutes to answer phone & 0.04 & n.s. \\
\hline Number of minutes to find information about company & 0.42 & $\mathrm{p}<0.01$ \\
\hline Average number of communication channels & -0.21 & $\mathrm{p}<0.05$ \\
\hline \multirow[t]{2}{*}{ Pleasantness of employee } & -0.18 & n.s. \\
\hline & $\begin{array}{l}\text { Mean years of } \\
\text { experience }\end{array}$ & Significance level \\
\hline \multicolumn{3}{|l|}{ Linking to product } \\
\hline Yes & 3.75 & $\chi^{2}=2.54$, n.s. \\
\hline No & 4.91 & \\
\hline \multicolumn{3}{|l|}{ Human contact } \\
\hline Yes & 5.20 & $\chi^{2}=3.79, p<0.05$ \\
\hline No & 4.24 & \\
\hline
\end{tabular}

technological abilities increase, the study reported here is among the first to address how online service varies depending on the characteristics of the industry and the firm. As such, it provides an important first step toward increasing understanding of how a firm might use online customer service to increase its competitive edge.

The results of the cross-industry analysis provide both good and bad news in regard to the state of online customer service. The bad news is that, consistent with studies of customer service provided in more traditional venues, the quality of customer service available online seems to be inconsistent and relatively poor. The good news, then, is that there seems to be plenty of room for newer, smaller firms to compete in this regard.

\section{Summary of results}

Firms in the more consumer-oriented industries of travel and retailing were more likely to provide toll-free numbers and less likely to provide e-mail addresses than companies in the manufacturing and technology industries.

More customer-oriented firms were no more likely to require personal information, but were more likely to add these visitors to an automatic mailing list.

Companies that accept credit cards were more likely to have a security statement than were companies that did not accept credit cards.

More customer-oriented travel and retail industries were significantly more likely both to provide a link to the product and to provide a human contact than were sites in the less customer-oriented manufacturing and technology industries.

Larger firms tend to answer customer service queries directed from the site more quickly than smaller firms are.

Sites with more experience were more likely to provide a link to the product, but were less likely to provide human operators.

\section{Customer communication}

Sites in the more customer-oriented industries of travel and retail are typically better than the less customer-oriented industries of manufacturing and technology at maintaining traditional communication channels, but lag behind when it comes to utilising non-traditional channels. Travel and retail sites were relatively less likely to provide an e-mail address and less likely to collect customer 
information. Those that did collect such information, however, were more likely to have automatic processes in place to maintain future customer contact.

The implications of these findings are twofold. First, they indicate that the opportunity exists to provide superior customer service simply by opening new channels of communication. For example, comparatively few retail and travel sites are set up to receive questions and comments via email and comparatively few technology companies offer a toll-free number. Across industries, only 17.8 per cent of sites provided customers with all three methods of communication. Of course, the costs of adding additional communication channels must be considered, as well as customer preferences and the ease of funnelling all communications through a single channel. As companies move to streamline their internal processes, however, they must be sure not to leave their customers behind.

Secondly, the results indicate that relatively few sites are set up to capture automatically customer information for use in future communications. Sites, particularly those in more customer-oriented industries, must carefully weigh potential concerns about consumer privacy, but should also remember that long-term customer communication is vitally important as return customers are the key to long-term profitability. To illustrate, research has found that online companies spend an average of US $\$ 250$ on marketing and advertising to acquire a single customer ${ }^{25}$ and that quarterly gross income from a loyal customer typically increases substantially from one period to the next. ${ }^{26}$

\section{Security}

A surprising low number of sites in the sample included a security statement.
Across industries, 58.5 per cent of sites did not have such a statement available to visitors. This is even more surprising considering that 43.6 per cent of these sites accepted credit card information for purchases or reservations. The safety and security of information is very important to today's online consumer and can be a major deterrent to purchasing online. ${ }^{27}$ True, concerns about credit card theft are likely to become less important as financial institutions offer guarantees and the use of disposable credit card numbers grows. It will, however, increasingly behove customer service sites, particularly those that collect vital information for their marketing databases, to make sure they address consumers' concerns about the use and protection of personal data.

\section{Quality of customer service}

Six measures of customer service were examined to determine the effects of customer orientation, firm size and online experience on service quality. The implications of the findings are discussed subsequently.

Customer orientation. With regard to customer orientation, the analyses produced mixed results. No effects were found for response time, time to answer questions, number of communication channels or the pleasantness of the experience. Significant effects were found, however, with regard to the likelihood of linking to product information and the ability to reach a human contact. The proportion of sites linking to product availability information was lowest for manufacturing firms (59.1 per cent). This is not unexpected, as such firms are likely to sell through the largest number of outlets. When possible, however, such linkages might provide an attractive way for a firm to bypass the competition of a retail store and speak directly to the end user. 
Company size. The findings in regard to the effects of company size on the quality of customer service were also somewhat equivocal. No effects were found for size on the amount of time it took to find information about the company, the number of communication channels, pleasantness or the likelihood of linking to product information. The results reveal, however, that larger companies take significantly less time to respond to customer service inquiries by phone, and, not coincidentally, are less likely to provide access to a live voice.

Web experience. The final hypothesis concerned the effects of online experience, measured by the number of years that the site name had been registered. Among the sites in the sample, experience had inverse relationships with both the number of communication channels available and the availability of human contact. These results imply that more experienced companies, like larger companies, have tended to streamline their customer service process by focusing on fewer, and more efficient methods of customer communication. As such, these findings indicate substantial room for improvement and differentiation by smaller firms which are willing to provide 'the human touch.' The researchers' ability to reach a real, live person to address customer service questions was surprisingly low (44.6 per cent overall). These results indicate the opportunity, particularly in those industries not typically known for a strong customer orientation, for differentiation from the competition through the 'deautomisation' of customer service practices.

\section{References}

1 Council of Better Business Bureaus (1999) 'BBB annual inquiry and complaint summary', Council of Better Business Bureaus, Arlington, VA.
2 University of Michigan (2001) 'American customer satisfaction index', 21st May, retrieved from the World Wide Web, 21st May, 2001, http://www.bus.umich.edu/research/nqrc/acsi.html.

3 International Customer Service Association (2001) 'ICSA/E-SATISFY.COM Study of electronic customer service' (publications page), retrieved from the World Wide Web, 21st May, http://www.icsa.com/public/pubs.

4 France, M. (1999) 'A site for soreheads,' Business Week, 26th April, p. 86.

5 Yahoo Category Listings, retrieved from the World Wide Web, 20th November, 2001

http://dir.yahoo.com/Society_and_Culture/Issues_and_Causes/Consumer_Advocacy_and_Information/Consumer_Opinion/Individual_Companies/

6 Taylor, S. (2000) 'New study identifies epidemic consumer disease: Post-transaction anxiety order', press release, retrieved from the World Wide Web, 21st May, 2001, http://www.infofarm.com/html/ 2_may_html.

7 Gantenbeim, D. (2000) 'What to do when they're ringing off the hook, Business 2.0, 29th September, retrieved from the World Wide Web, 21st May, 2001, http://www.business2.com/magazine/2000/ 09/20132.htm.

8 Allen, D. (2000a) ‘@ Your Service’, E-Marketer, 28th June, retrieved from the World Wide Web, 3rd November, 2000, http://emarketer.com/ayalysis/ ecommerce_b2c/20000628_service.html.

9 Jupiter Media Metrix (2001) 'Poor online service drives away brick \& mortar customers', press release 21st March, retrieved from the World Wide Web, 20th May, 2001, http://www.jup.com/company/ pressrelease.jsp?doc-pr010321.

10 Dineley, D. and Snyder, J. (2000) 'Customer service meets the Web', Infoworld, 31st March, retrieved from the World Wide Web, 18th May, 2001, http://infoworld.com/articles/ic/xml/00/04/03/.

11 Brown, J. (2000) 'Service, please', Business Week, 23rd October, pp. 48-50.

12 National Association of Consumer Agency Administrators and The Consumer Federation of America (2000) 'Ninth annual NACAA/CFA consumer complaint survey report', 21st November, retrieved from the World Wide Web, 22nd May, 2001, http://www.consumerfed.org/nacaasurv.pdf.

13 Gartner Group (2000) 'Lousy customer service on the Web', retrieved from the World Wide Web, 3rd May, 2001, http://gartner11.gartnerweb.com/public/ static/aboutgg/pressrel/pr200000808a.html

14 Narver, J. C. and Slater, S. F. (1990) 'The effect of a market orientation on business profitability,' Journal of Marketing, Vol. 54, October, pp. 20-35.

15 Gatignon, H. and Xuereb, J-M. (1997) 'Strategic orientation of the firm and new product performance,' Journal of Marketing Research, Vol. 34, February, pp. 77-90.

16 Narver and Slater (1990) op. cit.

17 For example, see Narver and Slater (1990) op. cit., ref. 1 above and Voss, G. B. and Voss, Z. G. (2000) 
'Strategic orientation and firm performance in an artistic environment,' Journal of Marketing, Vol. 64, January, pp. 67-83.

18 See Gatignon and Xuereb (1997) op. cit.

19 Kohli, A. K. and Jaworski, B. J. (1990) 'Market orientation: The construct, research propositions, and managerial implications,' Journal of Marketing, Vol. 54, April, pp. 1-18.

20 See Gatignon and Xuereb (1997) op. cit. and Kohli and Jaworski (1990) op. cit.

21 Wortzel, L. H. (1987) 'Retailing strategies for today's mature marketplace,' The Journal of Business Strategy, Vol. 7, No. 4, pp. 45-57.

22 Kleindl, B. (2001) 'Strategic electronic marketing: Managing e-business', SouthWestern Publishing Co., Cincinnati, Ohio.
23 Hoovers Online Business Network (2000) retrieved from the World Wide Web, 3rd August, 2000, http://www.hoovers.com.

24 Network Solutions (2000), retrieved from the World Wide Web. 3rd August, 2000, http://www. networksolutions.com.

25 Shop.org (2001) 'The state of online retailing 4.0', press release 2nd May, retrieved from the World Wide Web, 21st May, 2001, http://www.shop.org/ $\mathrm{nr} / 01 / 050201 . \mathrm{html}$.

26 Allen, D. (2000b) 'If you can't buy customers, keep 'em', E-Marketer, 1st November, retrieved from the World Wide Web, 3rd November, 2000, http://emarketer.com/etopics/articles/ 200001101_customers.html.

27 See Wortzel (1987) op. cit. 